\title{
Incremental extension of a paradigm shift
}

\author{
Christoph Haller, MD, and Christopher A. Caldarone, MD
}

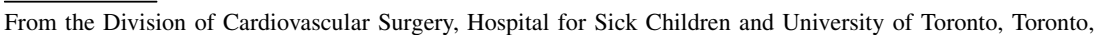 \\ Canada. \\ Disclosures: Authors have nothing to disclose with regard to commercial support. \\ Received for publication July 10, 2015; accepted for publication July 14, 2015; available ahead of print Aug 5, \\ 2015. \\ Address for reprints: Christopher A. Caldarone, MD, 555 University Ave, M5G 1X8 Toronto, Canada (E-mail: \\ christopher.caldarone@sickkids.ca). \\ J Thorac Cardiovasc Surg 2015;150:731-2 \\ $0022-5223 / \$ 36.00$ \\ Copyright (c) 2015 by The American Association for Thoracic Surgery \\ http://dx.doi.org/10.1016/j.jtcvs.2015.07.039
}

The absence of adequate therapeutic options has always been a strong driving force for innovation. Whether it was Helen Taussig and Alfred Blalock paving the way for congenital heart surgery with the subclavian to pulmonary artery shunt ${ }^{1}$ or the introduction of hybrid palliation in hypoplastic left heart syndrome, ${ }^{2}$ unmet needs sparked unorthodox thinking and new ways to solve surgical problems.

A paradigm shifted with the development of transcatheter valves in the pulmonary position ${ }^{3}$ and later in the aortic position. ${ }^{4}$ Since then, numerous investigators have demonstrated that these valve constructs also can be used as a fallback option in other situations unfavorable for surgery. Especially in congenital heart surgery, the available options for mitral valve replacement in small patients are limited by small dimensions and the mandatory need for growth of cardiac structures. The use of the Melody (Medtronic Inc, Minneapolis, Minn) valve in the mitral position was first described by the Boston group, ${ }^{5}$ who also published their extended experience with 11 patients undergoing mitral valve replacement. ${ }^{6}$ The valve is composed of a bovine internal jugular vein mounted in a platinum stent. The intriguing concept is that this valve not only covers a wide range of annular dimensions down to $10 \mathrm{~mm}$ but also leaves the potential for gradual re-dilation in a growing patient.

Trezzi and colleagues ${ }^{7}$ push the limits of the use of the Melody valve even further. With the smallest patient of the Boston series aged 2 months and weighing $3.5 \mathrm{~kg}$, they report their experience in 2 patients with body weights of $3.0 \mathrm{~kg}$ and $2.5 \mathrm{~kg}$. The small dimensions within the left atrium and ventricle pose the dominant challenge, which can be overcome by shortening the length of the construct by bending the crown struts. The current case report shows favorable early results, further extending the size range of potential recipients.

The limited experience with a reported follow-up of only up to 20 months ${ }^{6}$ leaves many questions unanswered. We still know little about the valve's long-term behavior in a high-pressure environment. Hasan and colleagues ${ }^{8}$ provide

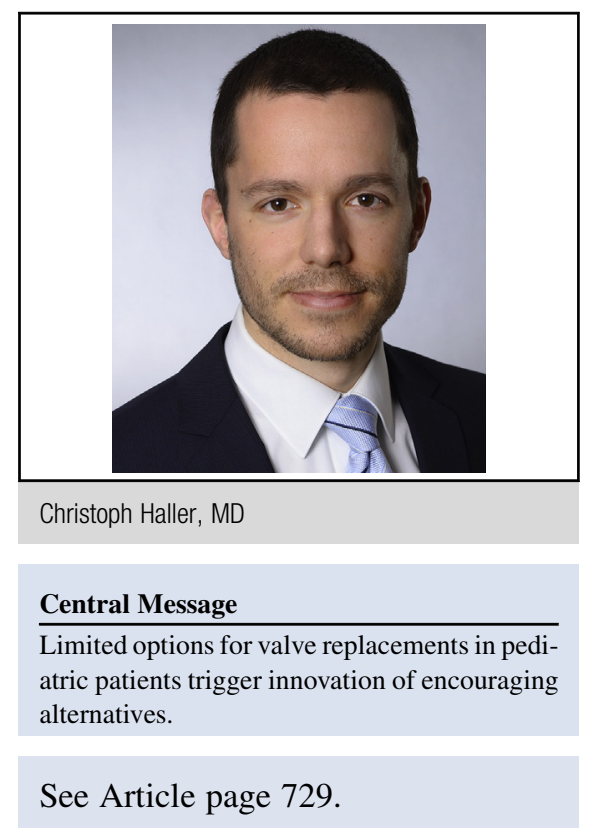

some limited favorable data on prosthetic performance in high-pressure environments. Long-term analysis will be required to assess the durability of the implanted valve in its initial configuration at the time of implantation. We have even less data available on the durability of the prosthesis after catheter-based dilation. ${ }^{6}$ Other important technical questions to resolve include the benefits or drawbacks of the use of a sewing ring for implantation, 6,9 the extent of resection of the subvalvular apparatus, ${ }^{6,9}$ or the application of a left ventricular fixation suture to maintain alignment.

Nevertheless, we witness another step forward to solve a troublesome clinical problem when mitral valve repair is not possible in very small patients. There is a growing body of evidence that mitral valve replacement with the Melody valve in patients with congenital cardiac and mitral valve disease not amenable to surgical repair is not only feasible but also may be a favorable option. And the paradigm shifts a bit further.

\section{References}

1. Blalock A, Taussig H. The surgical treatment of malformations of the heart in which there is pulmonary stenosis or pulmonary atresia. J Am Med Assoc. 1945; 128:189.

2. Akintuerk H, Michel-Behnke I, Valeske K, Mueller M, Thul J, Bauer J, et al. Stenting of the arterial duct and banding of the pulmonary arteries: basis for combined Norwood stage I and II repair in hypoplastic left heart. Circulation. 2002;105: 1099-103.

3. Bonhoeffer P, Boudjemline Y, Saliba Z, Merckx J, Aggoun Y, Bonnet D, et al. Percutaneous replacement of pulmonary valve in a right-ventricle to pulmonaryartery prosthetic conduit with valve dysfunction. Lancet. 2000;356:1403-5. 
4. Cribier A, Eltchaninoff H, Bash A, Borenstein N, Tron C, Bauer F, et al. Percutaneous transcatheter implantation of an aortic valve prosthesis for calcific aortic stenosis: first human case description. Circulation. 2002; 106:3006-8.

5. Abdullah I, Ramirez FB, McElhinney DB, Lock JE, del Nido PJ, Emani S. Modification of a stented bovine jugular vein conduit (melody valve) for surgical mitral valve replacement. Ann Thorac Surg. 2012;94:e97-8.

6. Quiñonez LG, Breitbart R, Tworetsky W, Lock JE, Marshall AC, Emani SM. Stented bovine jugular vein graft (Melody valve) for surgical mitral valve replacement in infants and children. J Thorac Cardiovasc Surg. 2013;148:1443-9.
7. Trezzi M, Cetrano E, Albano A, Carotti A. Extending the limits for mitral valve replacement in low-weight infants using a stented bovine jugular vein graft. J Thorac Cardiovasc Surg. 2015;150:729-30.

8. Hasan BS, McElhinney DB, Brown DW, Cheatham JP, Vincent JA, Hellenbrand WE, et al. Short-term performance of the transcatheter melody valve in high-pressure hemodynamic environments in the pulmonary and systemic circulations. Circ Cardiovasc Interv. 2011;4:615-20.

9. Hofmann M, Dave H, Hubler M, Kretschmar O. Simplified surgical-hybrid Me$\operatorname{lody}(\mathrm{R})$ valve implantation for paediatric mitral valve disease. Eur J Cardiothorac Surg. 2015;47:926-8. 